\title{
Emerging Issues and Potential Opportunities in the Rice-Wheat Cropping System of North-Western India
}

\section{OPEN ACCESS}

Edited by:

Min Huang,

Hunan Agricultural University, China

Reviewed by:

Hanuman S. Jat,

Central Soil Salinity Research Institute

(ICAR), India

Amit Kumar,

Central Muga Eri Research and Training Institute (CMERTI), India

*Correspondence: Sachin Dhanda dhanda@ksu.edu

Specialty section: This article was submitted to Crop and Product Physiology, a section of the journal

Frontiers in Plant Science

Received: 10 December 2021 Accepted: 31 January 2022

Published: 22 February 2022

Citation:

Dhanda S, Yadav A, Yadav DB and Chauhan BS (2022) Emerging Issues and Potential Opportunities in the Rice-Wheat Cropping System of North-Western India.

Front. Plant Sci. 13:832683. doi: $10.3389 /$ fpls.2022.832683

\author{
Sachin Dhanda ${ }^{1 *}$, Ashok Yadav², Dharam Bir Yadav ${ }^{3}$ and Bhagirath Singh Chauhan ${ }^{4,5}$ \\ ${ }^{1}$ Department of Agronomy, Kansas State University, Manhattan, KS, United States, ${ }^{2}$ Department of Agronomy, Chaudhary \\ Charan Singh Haryana Agricultural University (CCSHAU), Hisar, India, ${ }^{3}$ Department of Agronomy, CCSHAU Regional \\ Research Station, Karnal, India, ${ }^{4}$ Centre for Crop Science, Queensland Alliance for Agriculture and Food Innovation (QAAFI) \\ and School of Agriculture and Food Sciences (SAFS), The University of Queensland, Gatton, QLD, Australia, ${ }^{5}$ Department of \\ Agronomy, CCSHAU, Hisar, India
}

The rice-wheat cropping system (RWCS) is the backbone of Indian farming, especially in the north-western region. But continuous adoption of the RWCS in northwest India has resulted in major challenges and stagnation in the productivity of this system. Additionally, the Indo-Gangetic Plains of Pakistan, Nepal, and Bangladesh are also facing similar challenges for sustainable production of the RWCS. Several emerging problems, such as the exhausting nutrient pool in soil, deteriorating soil health, groundwater depletion, escalating production cost, labor scarcity, environmental pollution due to crop residue burning and enhanced greenhouse gas emissions, climatic vulnerabilities, and herbicide resistance in weed species, are a few major threats to its sustainability. To address these challenges, a wide range of sustainable intensification technologies have been developed to reduce the irrigation and labor requirements, tillage intensity, and straw burning. Awareness and capacity building of the stakeholders and policy matching/advocacy need to be prioritized to adopt time- and need-based strategies at the ground level to combat these challenges. This review summarizes the current status and challenges of the RWCS in the northwest region of the country and also focuses on the precision management options for achieving high productivity, profitability, and sustainability.

Keywords: environmental pollution, precision management, residue burning, soil health, water productivity

\section{INTRODUCTION}

The rice (Oryza sativa L.)-wheat (Triticum aestivum L.) cropping system (RWCS) plays a vital role in global food security as it provides staple foods to the world's population (Lalik et al., 2014; Banjara et al., 2021a). The RWCS is extensively cultivated and the most technologically advances system in the world. In Asia, 13.5 million hectares (mha) are grown, with $57 \%$ of it being in South Asia (Ahmad and Iram, 2006; Ladha et al., 2009). Furthermore, more than $85 \%$ of the RWCS practiced in South Asia is distributed in the Indo-Gangetic Plains (IGP; Banjara et al., 2021b). In India, the pre-dominant rice-wheat system covers an area of $9.2 \mathrm{mha}$, thus playing a key role in the nation's food security (Jat et al., 2020). India has a remarkable 
track record of cereal production from 87.4 million tons (mt) in 1961 to $324.3 \mathrm{mt}$ in 2019 (FAOSTAT, 2021). In India, rice occupies an area of nearly $43.8 \mathrm{mha}$, with a total production of $177.6 \mathrm{mt}$ and productivity of $4,057 \mathrm{kgha}^{-1}$, whereas, wheat has $29.3 \mathrm{mha}$ area, $103.6 \mathrm{mt}$ production, and $3,533 \mathrm{kgha}^{-1}$ productivity (FAOSTAT, 2021). Rice is the staple in the diet of $>70 \%$ of the Indian population, and the rest of the population consumes rice along with wheat or other grains (USDA, 2019).

The RWCS is widely spread in the north-western parts of India, especially Punjab, Haryana, and Uttar Pradesh, and most of these regions depend on groundwater for irrigation (Ambast et al., 2006). With the advent of the Green Revolution, the country's foodgrain production increased many-fold due to technological intervention; however, current cultivation practices in the RWCS are degrading the soil and water resources and thus threatening the sustainability of this system (Chauhan et al., 2012; Kumar et al., 2018). The crop productivity doubled in the last decade, which happened at the expense of mismanagement of inputs, resulting in a negative impact on the environment, biodiversity, soil quality, and air quality (Tilman et al., 2011; Godfray and Garnett, 2014).

Agriculture is responsible for around $16 \%$ of India's greenhouse gas emissions. Of this, $74 \%$ of agricultural greenhouse gas emissions are through methane from livestock (38.9\%) and rice (36.9\%; Vetter et al., 2017). The remaining 26\% comes from nitrous oxide emitted from fertilizers. The RWCS in north-western India is rapidly becoming unsustainable mainly due to rising production cost, depletion/degradation of natural resources, and declining input use efficiencies coupled with changing climate and other socio-economic conditions. There is clear evidence from the long-term experiments that the productivity of the RWCS is stagnating, and sometimes declining (Chauhan et al., 2012; Bhatt et al., 2021). The stagnation in the system yield might be due to an exhausted natural resource base along with adverse effects of changing climate (Pathak et al., 2003). Further, due to the high demand for labor, water, and energy, the sustainability of this system is now under question (Jat et al., 2009; Saharawat et al., 2010; Kumar et al., 2013b; Bhatt et al., 2021).

Historically, rice and wheat have had contrasting requirements for cultivation, as rice seedlings needed to be transplanted under puddled conditions, whereas wheat requires aerobic and well-pulverized soil. However, it is now well-established that rice can alternatively be grown very successfully under non-puddled transplantation or direct-seeding conditions, without a requirement for continuous flooding; similarly, wheat can also be established under no-till conditions (Jat et al., 2019b; Panneerselvam et al., 2020).

In the RWCS, the farmers in north-western India generally grow rice as a lowland crop from June to October, followed by wheat as an upland crop from November to April. The puddling in rice cultivation destroys soil structure, leading to poor soil aeration and soil compaction (Kumar et al., 2008; Pathak et al., 2011). Therefore, the continuous adoption of the RWCS has resulted in a hardpan at shallow depths that halts the root penetration/proliferation into the soil and thus affects the growth of the succeeding wheat crop. A decline in wheat yield ( $8 \%$ lower) was reported when it was sown after puddled transplanted rice compared to the wheat sown after direct-seeded rice (Kumar et al., 2008). The over-exploitation and poor management of groundwater lead to a drastic decline in the groundwater table (Humphreys and Gaydon, 2015).

Rice and wheat are the exhaustive cereal crops that lead to a heavy depletion of soil nutrients, and the problem is further aggravated when farmers burn the rice crop residue left in their fields after mechanized harvesting. The left-over rice residue in the fields interferes with tillage and sowing operations of the successive wheat crop; therefore, farmers usually prefer to burn rice residue. About $2 \mathrm{M}$ farmers in the northwest and some parts of eastern India burn an estimated $23 \mathrm{mt}$ of rice residue every year (NAAS, 2017). Air pollution from crop residue burning is a major cause of premature (human) mortality. In some northwest Indian cities, the particulate air pollution in 2017 exceeded more than five times the safe daily threshold limits causing severe health problems both in rural and urban areas (Central Pollution Control Board of India, 2017). Thus, the residues from the RWCS, especially the rice straw, are a challenge to manage timely and cost-effectively.

Because of all the challenges posed by the current situation, farmers need new alternatives to the present conventional intensive tillage and crop establishment methods to conserve water and sustain soil health and environmental safety. Also, there is a need to develop new technologies to conserve natural resources and improve input use efficiencies. The challenges and issues with the proposed solutions in the RWCS in northwest India are presented in Figure 1. This review mainly focuses on the importance of the RWCS in northwest India and prevailing and emerging concerns related to continuous adoption of this cropping system vis-a-vis alternate sustainable intensification technologies along with precision management options for achieving higher productivity, farm income, and sustainability.

\section{SIGNIFICANCE OF THE RWCS}

The RWCS is the largest agricultural production cropping system in the world and is more prominent in northwest India because of favorable agro-climatic conditions, ecological suitability, and availability of natural resources. Further, the irrigation facilities at nominal charges, assured procurement at a minimum support price, the availability of short-statured and high-yielding fertilizerresponsive as well as irrigation-responsive varieties, and good accessibility to machinery for sowing and harvesting operations favor the adoption of RWCS in northwest India. For these reasons, farmers are reluctant to diversify the existing RWCS. Also, farmers hesitate to shift toward resource conservation and sustainable intensification technologies, like direct-seeded rice, due to the risk of a lower yield than puddled transplanted rice (Kumar and Ladha, 2011).

Moreover, this system plays a major role in sustaining national food security and employs millions of rural people. Also, the RWCS gives stable income with less risk and acts as a mainstay for the livelihood of the farmers and many 


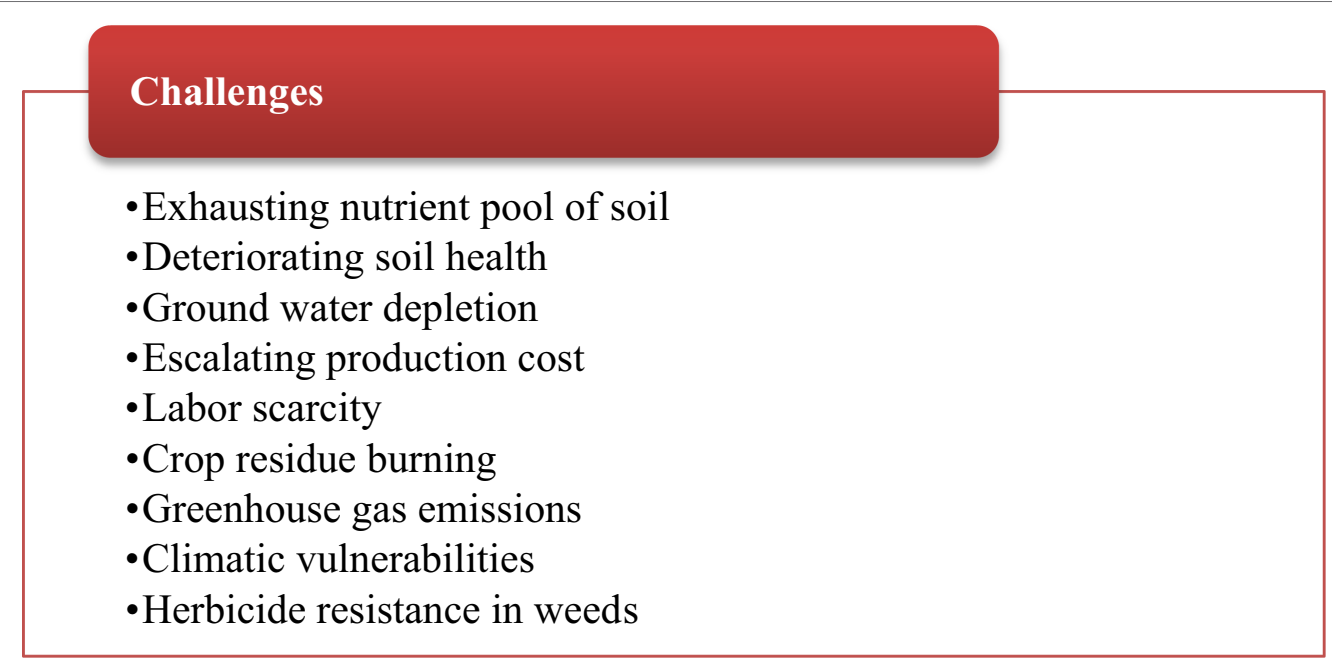

\section{Solutions}

- Crop diversification

- Conservation agriculture

- Direct seeded rice

-Alternate dry and wet method of irrigation in rice

- Furrow irrigated raised bed (FIRB) system of planting

-Automated irrigation systems

-Early sowing of zero-till wheat

- Residue management practices

-Precision nutrient management

- Short duration rice cultivars

-Awareness and capacity building of the stakeholders

-Integrated weed management with herbicide rotation

FIGURE 1 | Challenges of the rice-wheat cropping system in northwest India with proposed solutions.

other stakeholders. Therefore, the regions in northwest India are largely dependent on the monotonous RWCS. In the last few decades, high growth rates for food grain production (wheat $3.0 \%$ and rice $2.3 \%$ ) in India have kept pace with population growth. Rice productivity increased from $\sim 1,000 \mathrm{~kg} \mathrm{ha}^{-1}$ in 1960 to $3,420 \mathrm{~kg} \mathrm{ha}^{-1}$ in $2018-19$ in Haryana and $4,370 \mathrm{kgha}^{-1}$ in Punjab. Similarly, wheat productivity increased from $1,200 \mathrm{kgha}^{-1}$ in $1960-61$ to $4,850 \mathrm{kgha}^{-1}$ in 2018-19 in Haryana and $5,080 \mathrm{kgha}^{-1}$ in Punjab. However, the productivity growth in rice and wheat slowed down after 2000-01, followed by a widespread stagnation or decline in some locations (Statistical Abstract of Haryana, 2018-19; Statistical Abstract of Punjab, 2019; Haryana Economic Survey, 2019-20; Punjab Economic Survey, 2019-20). Evidence is now appearing that the rice-wheat system productivity is plateauing because of a fatigued natural resource base.

\section{TRADITIONAL PRODUCTION PRACTICES AND CHALLENGES}

Conventional rice cultivation in the RWCS is characterized by intensive puddling followed by transplanting of 25- to 30-dayold seedlings, maintaining standing water in paddy fields for 2 weeks, and thereafter re-applying irrigation 2 days after the ponded water has disappeared due to infiltration into the soil (Anonymous, 2020; Dhillon et al., 2021). This practice offers some benefits, such as competitive advantages against weeds and poor oxygen diffusion that restricts the germination of weeds, assured anaerobic conditions with a neutral soil reaction, and greater availability of nutrients, such as iron (Bhatt and Kukal, 2015). The cultivation of puddled transplanted rice is followed with multiple tillage operations to create a fine seedbed for the wheat crop. 
The short turnaround time between rice harvest and wheat planting, and farmers' mindset to employ excessive preparatory tillage primarily delay wheat planting, resulting in yield losses of $32 \mathrm{~kg} \mathrm{ha}^{-1}$ day $^{-1}$ when planted after 15 November in northwest India (Tripathi et al., 2005), and even as high as $35 \mathrm{kgha}^{-1} \mathrm{day}^{-1}$ in other regions of the country. Wheat sowing can also delay because of the planting of medium duration (140 days) basmati rice or long-duration coarse rice varieties. The fields are kept as fallows for $2-3$ months between wheat harvest and rice establishment. This conventional system for the cultivation of the RWCS has led to many challenges, which are discussed below.

\section{Soil Health}

The conventional system for rice cultivation includes puddling (tillage under wet conditions) for reducing the percolation losses, for ease of seedling transplantation, and to suppress weeds. But the continuous adoption of this system has resulted in several negative effects on soil health (Nandan et al., 2021). Repeated puddling in coarse and medium-textured soils has resulted in subsurface compaction, which affects the cultivation of successive upland crops, such as wheat, by restricting the root growth and causing aeration problems (Hossain et al., 2021; Saurabh et al., 2021). Puddled transplanted rice, when following a wheat crop, exposes the hidden organic matter to air and results in its oxidation, thus leading to structural degradation of the soil.

Further, intensive tillage results in the destruction of large aggregates, which ultimately leads to low crop yields. The continuous RWCS is also found to disturb the nutrient balance in the upper vadose zone (Gill, 1992). The burning of rice residues results in loss of nutrients in bulk (Kumar et al., 2019), as a result, farmers have to apply additional fertilizers, which results in a higher cost of cultivation and also reduces the soil quality in the long run. Thus, the continuous RWCS severely affects soil health. A decrease in soil organic carbon of $0.9 \mathrm{tha}^{-1}$ was reported under a continuous 7-year RWCS in the IGP of India (Sapkota et al., 2017). However, there are divergent opinions regarding the organic carbon and soil fertility under the RWCS.

Bijay-Singh et al. (2005) concluded that the long-term soil fertility experiments on the RWCS progressing in the IGP do not support the sweeping statements that soil organic matter in the entire rice-wheat belt of India is declining. Soil organic matter levels in some areas of the rice-wheat belt are declining only where unbalanced use of fertilizers is being practiced and very little recycling of crop residue and other organic inputs occurs. Yadav et al. (2000) analyzed the data of longterm experiments in the RWCS conducted for $12-15$ years at seven locations, which revealed that soil organic carbon decreased overtime at locations where the initial organic carbon content was greater than $0.65 \%$, but increased at locations having low initial organic carbon $(<0.50 \%)$. Lal (2004) considered lowland rice-based production systems the most stable and soil organic carbon conserving system. However, the RWCS is showing signs of fatigue because of the continuous use of traditional practices which resulted in yield stagnation and declining factor productivity (Bhatt et al., 2016, 2021). Higher yields are being sustained with an increased quantity of nutrients, which is also an indirect indication of deteriorating soil health.

\section{Residue Burning}

Haryana and Punjab together produce $28.1 \mathrm{mt}$ of paddy straw (2018 estimates) out of which $40 \%(11.3 \mathrm{mt})$ is burnt in the fields, and $60 \%$ is managed through soil incorporation and other measures (DACFW, 2019). These two states of India accounted for 12 and $88 \%$ of the straw burnt, respectively (DACFW, 2019). Management of residue is a major problem in the RWCS. The wheat residue is not a major concern as it is used in the animal husbandry sector but rice residue $\left(6-8\right.$ tha $\left.^{-1}\right)$ is not suitable for the dairy sector because of its low digestibility, poor palatability, low protein, and high silica content (Arora and Sehgal, 1999). Also, the incorporation of undecomposed fresh rice straw immobilizes nitrogen in the soil as it has wide carbon: nitrogen ratio (Singh and Sidhu, 2014). Therefore, farmers usually resort to the burning of rice residue, which leads to several problems.

Particulate air pollution from crop residue burning affects the local population and downwind communities. Seasonal rice residue burning is estimated to contribute as much as $26 \%$ of the country's capital's (Delhi) air pollution in the winter months (Sharma and Dikshit, 2016). The effect of residue burning is evident when an international cricket match was interrupted in Delhi because of high pollution (15 times the World Health Organization limits). ${ }^{1}$ The cricket sport plays an important role in the Indian economy; therefore, residue burning indirectly affects the Indian economy. Even some countries have suspended their flights to Delhi during this pollution phase. $^{2}$

Residue burning imposes enormous public health and economic burden caused by air pollution (Balwinder-Singh et al., 2019). Catastrophic spikes in air pollution are increasingly common in northwest India in the fall season following rice harvest. Such burnings result in perturbations to the regional atmospheric chemistry due to emissions of trace species like carbon dioxide, carbon monoxide, methane, nitrous oxide, and aerosols (Gupta et al., 2004). Fine particulate matter (particulate matter of 2.5) is particularly of concern when values exceed $700 \mu \mathrm{g} \mathrm{m}^{-3}$ in some cities and concentrated burning is the major contributor to poor air quality in northwest India (Balwinder-Singh et al., 2019). Moreover, residue burning causes removal of nutrients, especially potassium, and $80-85 \%$ of which is absorbed by rice and wheat residues in their straw (Singh et al., 2008). Therefore, to address all these major issues, scientists have suggested different in situ and ex situ measures to the farmers and, depending upon their socio-economic and cultural status, one could choose a better option for the judicious use of the straw residue. As an example, the rice straw can be managed by using it as manure or to produce energy, ethanol, biogas, and biochar (Lohan et al., 2018).

${ }^{1}$ www.theguardian.com/world/2017/dec/03/

pollution-stops-play-at-delhi-test-match-as-bowlers-struggle-to-breathe ${ }^{2}$ www.hindustantimes.com/delhi-news/delhi-air-pollution-united-airlinessuspends-flights-to-capital-due-to-poor-air-quality/story-

srziMMH6HtVpy6rcNcQpHN.html 


\section{Herbicide Resistance}

The continuous use of a single herbicide in rice for the control of Echinochloa spp. resulted in the emergence of new hardy weeds like Leptochloa chinensis (L.) Nees, Cynodon dactylon (L.) Pers., Ischaemum rugosum Salisb., Paspalum distichum L., Ludwigia hyssopifolia (G. Don) Exell, Eclipta prostrata L., Cyperus rotundus L., Cyperus iria L., Cyperus difformis L., and Fimbristylis miliacea (L.) Vahl (Mahajan et al., 2012; Shekhawat et al., 2020; Dhillon et al., 2021). Due to the monocropping of the RWCS, the infestation of Phalaris minor Retz. has increased in wheat, as paddy cultivation provides favorable conditions for the germination of P. minor (Franke et al., 2003). Farmers have applied herbicides with similar modes of action year after year, which resulted in strong selection pressure for the resistant biotypes of $P$. minor, and ultimately the spread of resistance increased manifold in many regions of northwest India, especially Haryana and Punjab.

At present, $P$. minor has evolved with multiple resistance to three modes of herbicidal action, namely, acetyl-coenzyme A carboxylase (ACCase), acetolactate synthase (ALS), and photosystem II (PS II) inhibitors (Chhokar and Sharma, 2008; Yadav et al., 2016). Resistance in P. minor has been reported to isoproturon, clodinafop-propargyl, fenoxaprop-p-ethyl, sulfosulfuron, mesosulfuron-methyl, iodosulfuron-methylsodium, pyroxsulam, and pinoxaden. Farmers at some locations in the Karnal and Kaithal districts of Haryana even applied 3-4 times the recommended dose of herbicides during 2017-18 and ended up with unsatisfactory control ( 70\%; Singh et al., 2021). Recently, farmers have started using pendimethalin (750-1,000 g a.i. ha $\left.{ }^{-1}\right)$ as pre-emergence and metribuzin (50-140 $\mathrm{g}$ a.i. $\mathrm{ha}^{-1}$ ) as post-emergence tank-mix, in addition to the recommended herbicides to get desirable control (Singh et al., 2021). This study also revealed an increase in the cost of cultivation by $6.6 \%$ to manage $P$. minor in wheat, and an extra amount of around USD 38 million was spent annually by farmers in the RWCS of Haryana.

In the present situation, the pre-emergence application of pendimethalin, followed by post-emergence application of ACCase or ALS inhibitor herbicides, and tank or premix with metribuzin can control isoproturon and fenoxaprop-resistant P. minor (Chhokar and Sharma, 2008; Yadav et al., 2016). The application of pyroxasulfone has been found to be effective in controlling multiple resistant biotypes of $P$. minor (Kaur et al., 2019). As farmers moved toward zero tillage sowing, weed flora also got shifted, and a greater infestation of broadleaf weeds than grass weeds was reported (Chhokar et al., 2007, 2012). The same practice of continuous application of a herbicide with a similar mode of action also resulted in resistance in Rumex dentatus L. to metsulfuron-methyl, and cross-resistance to florasulam, pyroxsulam, iodosulfuron, and triasulfuron (Chhokar et al., 2017; Dhanda et al., 2020; Chaudhary et al., 2021).

\section{Groundwater Depletion}

The continuous adoption of the RWCS resulted in a decline in the water table, which ultimately affected crop, land, and water productivity. The Haryana and Punjab states in northwest parts of India are producing rice at the cost of their natural resources (Dhillon et al., 2010), which have been dwindling very fast. The conventional system of rice cultivation is a high-water demanding system (Bhatt and Kukal, 2018; Bhatt et al., 2020). Further, there is a large amount of loss of irrigation water during conventional rice cultivation in the northwest IGPs mainly in coarse-textured soils (Hira, 2009). Since the 1970s, groundwater has been continuously pumped, resulting in its declining level in northwest India, as an aftermath of the Green Revolution (Hira et al., 2004). The mean groundwater depletion in the Punjab state was about $8.91 \mathrm{~m}$ between 2000 and 2019 (Sidhu et al., 2021).

The decline in the groundwater table also resulted large investments into tube wells, which increased operational costs and led to more power consumption in northwest India (GoI, 2017), and the deterioration of groundwater quality (Farmaha et al., 2021). The management of groundwater is one of the major priorities to combat the challenging issue of water scarcity in India. Due to an over-reliance on groundwater and poor alternative infrastructure in the northwest IGP, the groundwater levels are declining at 0.1 to 1.0 meters every year (Hira et al., 2004; Bhatt et al., 2020). Based on the Central Ground Water Board report, out of 138 blocks monitored in Punjab, 80\% were categorized as overexploited, and the remaining $16 \%$ were considered safe (CGWB, 2019). Similarly, in Haryana, 61\% of the blocks were categorized as overexploited, and $20 \%$ safe. This is primarily because of the rice area expansion over time and continuing high groundwater withdrawal for irrigating rice.

About $92-96 \%$ of groundwater withdrawal in Punjab and Haryana is used for irrigation purposes. Because of the declining water table, the farmers are further compelled to deepen their tube wells and switch from centrifugal to submersible pumps, which has further escalated the production cost and challenging the overall sustainability of the existing cropping system. Annual per capita water availability in northwest India is supposed to decrease from $1,600 \mathrm{~m}^{3}$ to $1,000 \mathrm{~m}^{3}$ by 2025 (Mahajan et al., 2011). It was estimated that a reduction in the evapotranspiration from the RWCS of about $150 \mathrm{~mm}$ per year was needed to stop this groundwater decline (Humphreys et al., 2010).

\section{Economics}

Rice is a labor-intensive crop, and both Punjab and Haryana are largely dependent on migrant labor for its cultivation. From 2005-06 to 2018-19, both states' labor costs had increased exponentially from USD 1.27 to 3.78 per day in Haryana, and USD 1.35 to 3.22 per day in Punjab, respectively $(1 \mathrm{USD}=74.32$ Indian rupees; Sudhir-Yadav et al., 2017). This has increased transplanting costs approximately from USD 47 per ha in 2010 to USD 74 per ha in 2015, and it is rising every year thereafter. In addition, the gap between the overall costs of cultivation and the minimum support prices (proxies of market prices) of rice and wheat crops, even after adjusted for inflation effects, have increased over the years, adversely affecting the overall profitability and farm income. The RWCS, however, still remains the most preferred cropping system in northwest India because of its advantages like assured price and marketing, and stability in yield levels (Bhatt et al., 2021). 
Although the RWCS has been sustaining over the years, since the 1990s the productivity showed stagnation (Bhatt et al., 2021), connoting that the pace of productivity from the Green Revolution was slowing down. There is a need for crop rotation, instead of sticking solely to the RWCS. The crop rotation will not only save the resource base, including water, but also give higher economical returns. A study conducted at Ludhiana, India, revealed that inclusion of maize-potato-onion; summer peanut-potato-pearl millet (fodder), and maize-potato-summer mung bean gave 32, 25, and $23 \mathrm{tha}^{-1}$ annum $^{-1}$ rice equivalent yield, respectively, as against $12.9 \mathrm{tha}^{-1}$ annum ${ }^{-1}$ in the RWCS (Walia et al., 2011). Substitution of rice with maize or sugarcane was found more profitable than the RWCS (Kang et al., 2009; Choudhary et al., 2018a).

\section{ALTERNATIVE PRODUCTION TECHNOLOGIES AND ASSOCIATED BENEFITS}

For the last three decades, several studies have been concentrating on identifying viable, sustainable, and eco-friendly alternatives to the RWCS (Singh et al., 2020; Banjara et al., 2021b). To improve the deteriorating soil health, reduce groundwater depletion, residue burning, and environmental pollution, and ultimately to enhance farm incomes in a sustainable manner, sustainable agriculture-based technologies need to be adopted at the field level. The inclusion of legume crops in the RWCS, or crop diversification, crop residue management, conservation agriculture, and the adoption of water-saving technologies, can definitely help to increase the land and water productivity in the RWCS in northwest India. Some of the sustainable intensification technologies along with precision management options are discussed below.

\section{Crop Diversification}

There are several benefits associated with crop rotations other than the RWCS. The cultivation of pulses or oilseed crops instead of rice resulted in the improvement of soil health, reduced the water requirement, and increased water productivity (Arora et al., 2020). A study in Punjab, India, revealed that the soybean-wheat system under a raised bed system improved soil fertility and also saved water compared with the RWCS (Ram et al., 2013). Thus, the inclusion of legumes in the cropping system enhanced the nitrogen economy and also contributed to cropping systems' sustainability (Arora et al., 2020). Conservation agriculture-based opportunistic diversification (e.g., rice-wheat-mung bean) and strategic diversification (e.g., maize-wheat-mung bean) increased soil organic carbon by 83 and $72 \%$, respectively, as compared to rice-wheat (4.6 $\mathrm{g} \mathrm{kg}^{-1}$; Choudhary et al., 2018b).

Moreover, under a strategic scenario, lower soil bulk density and a higher soil quality index were recorded over the ricewheat-mung bean system (Choudhary et al., 2018b). The maize-wheat-mung bean and pigeon pea-wheat cropping systems resulted in a significant increase in total soil organic carbon of about 11 and $10 \%$, respectively, as compared to the conventional maize-wheat system (Venkatesh et al., 2017). The substitution of rice with crops that require less water, such as cotton, maize, pearl millet, or legumes in the summer, will allow the water to be replenished during the monsoon season and will increase the water productivity in northwest India. There was a substantial reduction in the irrigation water requirement when the RWCS shifted toward a cotton-wheat or maize-wheat system (Arora et al., 2008).

The maize crop can be a viable alternative to replace puddled transplanted rice in northwest India because of several benefits associated with it. Maize needs $80-85 \%$ less water and only one-fourth of water is required to produce $1 \mathrm{~kg}$ of grain as compared to rice (Bouman, 2009). The water productivity of maize was 8-22 times higher than rice (Gathala et al., 2013). Similarly, the irrigation water productivity of the maize-wheat system was $126-160 \%$ higher than the RWCS. Furthermore, the maize-wheat system also improved the soil health in comparison with the puddled transplanted rice system (Jat et al., 2012). The substitution of rice with maize in the RWCS enhanced the total microbial and enzymatic activities in soil, such as phosphatase, invertase, $\beta$-glucosidase, and urease (Wei et al., 2015).

It was reported that the activity of alkaline phosphatase and dehydrogenase, and the amount of carbon and nitrogen in the microbial biomass were higher under the maizewheat-mungbean system than the RWCS (Choudhary et al., 2018b). Governments in north-western Indian states are increasingly interested to diversify the intensified rice-wheat systems, more so to shift from rice to an alternative crop that requires less irrigation water, minimizes residue burning, and reduces labor scarcity. Based on long-term trials in Haryana, India, Kumar et al. (2018) reported that replacing rice with zero-till maize resulted in multiple benefits: $82-89 \%$ savings in irrigation water, $49-66 \%$ savings in total energy input, $13-40 \%$ reductions in global warming potential, and $27-73 \%$ higher profitability with similar or higher rice equivalent yield as compared to rice cultivated by transplanting or direct-seeding methods. Similar results were also reported by Jat et al. (2020).

Strategies to manage water demand and reduce crop burning in northwest India include modification in the cropping calendar, a suitable choice of crops and their varieties, and changes in cultivation practices. The prevalent government policies in Punjab and Haryana favor the cultivation of rice and wheat. The government's attempts to replace rice with less waterrequiring crops have not succeeded so far because of policies favoring these two crops, such as subsidized/free electricity for irrigation, assured output markets, minimum support price (MSP) guarantees, and a lack of suitable and remunerative alternative crops for diversification. The government has started to focus on pulse crops with strategically raising the MSP in the recent years. Alternate policies with strong advocacy could encourage farmers to downsize the stretch of rice-wheat farming in these states and diversify to more for high-value crops, such as vegetables, fruits, and flowers suited to specific environments. 


\section{Crop Residue Management}

Crop residue management in the RWCS is a major challenge because the loose and scattered residue causes hindrance in tillage operations and wheat sowing through conventional tillage becomes difficult and energy-intensive. The farmers in northwest India opt for the burning of residue eventuating in several hazards. For the last so many years, different innovative rice residue management strategies have been developed including in situ residue incorporation and zero-till sowing of wheat with surface-retained rice residue. These technologies have many benefits over rice residue burning, such as improving soil health, creating a positive nutrient balance in the soil, decreasing environmental pollution, and ultimately lowering the cost of cultivation.

Singh et al. (2019) reviewed crop residue management in the RWCS and outlined its importance for resource conservation, environmental protection, and sustainability in northwest India. Rice residue burning was monitored by using multiple satellites with thermal sensors during the rice harvest and wheat sowing season period from 30 September to 30 November in northwest India, mainly in Punjab, Haryana, and Uttar Pradesh, and it was found that in Punjab there was about 11 and $42 \%$ reduction in the number of burning events in 2018 as compared to that in 2017 and 2016, respectively (Singh et al., 2019). The reduction in number of burning events was about 29 and $41 \%$ in Haryana and 24 and $32 \%$ in Uttar Pradesh in the corresponding years. The adoption of in situ crop residue management practices was found to be the best remedy against crop residue burning.

The development of the zero tillage drill enables the direct sowing of wheat without preparatory tillage and removal of rice residue from the fields. Further, the improved version of zero tillage drills with the Turbo Happy Seeder can sow the wheat seed directly in the standing and lose rice stubbles, just after the harvesting of rice (Sidhu et al., 2015). These inventions are economically viable and increase water use efficiency. Different types of machinery available with the farmers to manage the rice straw include seeders for crop sowing under rice straw conditions (rotary disc drill, Turbo Happy Seeder, zero-seed drill, spatial no-till drill, and super seeders), straw cutter machinery for in situ incorporation/retention of rice straw (rice straw chopper, straw shredder, super straw management system and mulcher), machinery for straw incorporation (reversible moldboard plow and rotary-till-drill), and straw collection and disposal (raker and baler). The use of straw for biochar, biogas, and other forms of energy are slowly gaining importance but the considerable investment and time required to setup these enterprises is a major reason for the slow rate of shift of farmers. A delineation of a complete set of practices is lacking for the succeeding crops, such as wheat, potato, and/or vegetables.

\section{Sustainable Intensification Technologies}

Conservation agriculture has emerged as a promising technology to get maximum efficiency of the inputs and to sustain the productivity of the RWCS. Conservation agriculture works on the three fundamental principles, namely, crop diversification, zero or reduced tillage, and residue retention (Farooq and Siddique, 2014), and can help in carbon sequestration and improvement in physicochemical properties of soils (Jat et al., 2019a,b). Studies revealed that practicing sustainable intensification technologies in conservation agriculture systems have resulted in soil health improvement after 3-5years under the RWCS in the northwest IGP (Bhatt and Kukal, 2015). Further, the retention of residue also helps conserve soil moisture, regulate soil temperature, and enhance water use efficiency (Kukal et al., 2014; Bhatt and Kukal, 2018).

Dry direct-seeded rice (DDSR) has evolved as a potential alternative to puddled transplanted rice. In the DDSR system, the seeds of rice are sown with or without tillage and irrigation. Irrigation is applied at certain intervals to maintain the soil at the field capacity. Between 11 and $18 \%$ of water can be saved in the DDSR system, and the labor requirement is reduced by 11-66\% when compared to puddled transplanted rice, depending on the season and location (Kumar et al., 2009; Rashid et al., 2009). Further, DDSR also provides other advantages, such as easier and smoother planting, better soil health, and less methane emission (Pathak et al., 2009; Kumar and Ladha, 2011). Rice grown using the DDSR system also matures 7-10 days earlier compared to puddled transplanted rice, and thus allows timely planting of the successive wheat crop (Singh et al., 2006). But the major challenge in DDSR is the potential for a higher infestation and more diverse flora of weeds than puddled transplanted rice (Rao et al., 2007; Singh et al., 2007; Chauhan, 2012). Weeds in the DDSR system can cause a yield loss of 50-90\% (Chauhan and Johnson, 2011; Chauhan and Opena, 2012).

During the initial phase of the DDSR (2010-15), the rate of adoption was very good in northwest India. It was reported that the area under DDSR in Punjab was once reached as high as 160,000 ha during 2016 , but then declined to 5,000 ha by the year 2018 (Dhillon and Mangat, 2018). The major reasons for the declining area under DDSR were the lack of suitable rice varieties for late planting, too wet soil for dry seeding, and high weed infestations, which led some farmers to plow the crops. But due to labor shortage (migration) because of the lockdown in India in response to the COVID-19 pandemic, the area under DDSR was estimated to be increased to 200,000250,000 ha in Punjab during 2020 (Humphreys and Christen, 2020). Actually, it was reported that the area under DDSR in Punjab was 500,000 ha in $2020 .^{3}$ Enthusiastic with such a response by farmers, the Punjab state government has set a target of $0.8 \mathrm{mha}$ in 2021 (Kaushal, 2021), and the latest estimates indicate the DSR area in Punjab and Haryana during 2021 is around 0.6 and 0.02 mha, respectively.

Similarly, the planting of wheat under zero tillage after the rice harvesting had been widely adopted by the farmers in northwest India, especially Punjab, Haryana, and Uttar Pradesh. The area under zero-till wheat after the partial burning of the rice straw significantly increased since the late 1990s because of the reduction in the cost of cultivation by excluding

${ }^{3}$ www.pau.edu/index.php?_act=manageEvent $\& D O=$ viewEventDetail\&intEv entID $=5271$ 
preparatory tillage along with higher yields associated with timely sowings (Gupta and Sayre, 2007). Additionally, zero-till sowing also improved soil quality, prevented soil erosion, enhanced soil microbial activities, reduced weed infestation, reduced termite attack, and increased resource-use efficiency (Hobbs et al., 2008). The direct sowing of wheat with a zerotill seed drill in the combine-harvested rice fields is a challenge because loose rice straw in narrow swaths interferes with wheat sowing, resulting in non-uniform placement and germination of seeds.

This problem has been largely resolved by the development of new machinery, such as turbo Happy Seeder and rotary disc drill (Sidhu et al., 2007), which help by simultaneously surface mulching the rice straw while directly sowing the wheat under no-till conditions. Zero-till wheat was recommended during 2002-2005 in northwest India and now more than 2,500 and 3,400 numbers of zero-till seed-cum-fertilizer drills are functional in Haryana and Punjab, respectively, contributing to wheat seeding largely without any tillage or at least with reduced/conserved tillage (1-2 plowings in place of the 4-6 plowings that were commonly employed under conventional tillage).

The Happy Seeder was commercially introduced in northwest India almost 15 years ago. After multiple modifications, this technology has also been successfully adopted by the farmers. As per the 2018-19 report, approximately 2,400 and 9,800 units of Happy Seeder are functioning in Haryana and Punjab covering an area of 0.053 and $0.45 \mathrm{~m}$ ha of wheat, respectively (Singh, 2018). Overall, the area coverage under DDSR and zero-till wheat/Happy Seeder in India has been reported to be around $7.2 \mathrm{mha}$ (Pradhan et al., 2018) and $0.8 \mathrm{mha}$ (Singh, 2018), respectively.

Super seeders, like a combined version of the Happy Seeder and a rotavator, are also in place to accomplish wheat sowing in fields with full rice residues in one pass, but have a higher energy demand (50-60 H.P. tractor) and fuel consumption $\left(\sim 20 \mathrm{~L} \mathrm{ha}^{-1}\right)$. Additionally, non-synchronous and non-uniform germination, poor tillering, higher nutrient demand to ameliorate their deficiencies, non-synchronous crop maturity, and ultimately a significant decline in wheat yields are adverse effects associated with this intervention. Similar incidences in wheat have already happened with rotavators. Consequently, the farmers are also gradually losing their interest in wheat sowing by using super seeders.

The Punjab and Haryana state governments have now made it compulsory for all self-propelled combine harvesters to have a "Super Straw Management System," which helps in chopping and spreading the straw from the harvester. The uniform spreading of the loose residues is very important for a uniform and good crop stand using the Happy Seeder. It was reported that sowing wheat with the turbo Happy Seeder under rice residue conditions increased the wheat yield by $3.2 \%$ in comparison with conventional till sowing (Sidhu et al., 2015; Bhatt et al., 2021). The zero-till sowing of wheat with the retention of rice residue enhanced the productivity of the RWCS along with creating a positive nutrient balance and improved soil health (Sah et al., 2014).
The governments of Haryana, Punjab, Uttar Pradesh, and Delhi are helping the farmers by providing a subsidy $(50 \%$ to an individual farmer and $80 \%$ to co-operative societies) on agricultural machinery for the rice straw management and to control the pollution due to residue burning. Also, the governments are organizing awareness campaigns through demonstrations, information dissemination, school curriculum, and using different tactics of information and communication technology for effective management of crop residues. The increase in the number of service providers, individuals, or through custom hiring centers, assisted by several government subsidy schemes, has enhanced farmers' access to these machines.

Based on the data available from the Punjab Remote Sensing Centre (2019), the area under Happy Seeder sown wheat crops in Punjab was $0.55 \mathrm{~m}$ ha while it was not possible for remote sensing technology to assess the area under residue incorporation. It was estimated that nearly $0.8 \mathrm{mha}(19 \%)$ of the area was sown under zero-till wheat (using Happy Seeder and zero-till drill) in Punjab and Haryana together during 2018-19. For getting the maximum benefit of zero tillage, both rice and wheat need to be grown in zero-till conditions (Bhushan et al., 2007). However, DDSR in moist soil (sowing in well-prepared fields after pre-sowing irrigation or rains) has been found to be promising across landscapes and ecosystems, and it is gaining increasing importance in Punjab and Haryana, more particularly due to huge labor shortage (migration) during summer seasons of 2020 and 2021 under the effect of COVID-19 pandemic (Workie et al., 2020; Kaur and Kaur, 2021).

The sustainable production of the RWCS includes zero tillage with the retention of crop residue and the inclusion of legumes and Sesbania green manure in the system (Bhatt and Kukal, 2018; Yadav et al., 2019). The practice of conservation agriculture with precision irrigation management and replacing rice with low water demanding crops can help to achieve the goal of sustainable crop production in northwest India. It was reported that zero-till DDSR, followed by zero-till wheat, followed by zero-till mung bean resulted in higher system productivity (15-17\%) as compared to conventional puddled transplanted rice followed by conventional wheat (Kumar et al., 2018).

Due to other concerns (nematodes, insect pests, and lower yields) associated with long-term zero-till DDSR, dry seeding in moist soil is now more preferred and a potential alternative across the northwest and eastern ecologies. This helps in saving irrigation water, labor, fuel, cost, and drudgery, besides resulting in higher system productivity (more yield of the succeeding crop in sequence), conservation of natural resources, and environmental safety through reducing the emission of methane (>90\%) and overall global warming potential (20\%).

The DDSR followed by zero tillage wheat (ZTW) on longterm basis may be a viable and economical alternative to the conventional rice-wheat system. A medium term (7-year) study on DDSR-ZTW in Haryana, India was realized a better alternative in cutting cost of cultivation (USD $448 \mathrm{ha}^{-1}$ ) as compared to the puddled transplanted rice in sequence with conventional till wheat (USD 555 $\mathrm{ha}^{-1}$; Yadav et al., 2021). In rice, there was a saving in preparatory tillage (USD $55 \mathrm{ha}^{-1}$ ), seed/nursery establishment (USD $55 \mathrm{ha}^{-1}$ ), irrigation cost (USD $29 \mathrm{ha}^{-1}$ ), and 
saving of human labor (25 man-days ha ${ }^{-1}$ ) under DDSR-ZTW; however, weed management cost got increased due to dependence on costly herbicides (Table 1).

The emission of methane from the soil in puddled transplanted rice ranged from 0.8 to $1.9 \mathrm{t} \mathrm{CO}_{2}$ equivalent $\mathrm{ha}^{-1}$ in various districts of Punjab compared to only $0.1-0.3 \mathrm{t}$ $\mathrm{CO}_{2}$ equivalent $\mathrm{ha}^{-1}$ in DDSR (Gartaula et al., 2020). The average global warming potential due to all the three greenhouse gases (carbon dioxide, methane, and nitrous oxide) in transplanted rice was $2.91 \mathrm{tha}^{-1}$ compared to $1.94 \mathrm{tha}^{-1}$ in DDSR (Gartaula et al., 2020). Gupta et al. (2016) reported significantly low methane emission (82-87.2\%) in the DDSR as compared to the puddled transplanted rice. DDSR leveraged with short or medium duration rice varieties/hybrids with early maturity and faster field vacation helps in conserving residual soil moisture useful for crops in rotation, widening the time window for effective residue management, and also facilitates in early or timely sowing of long-duration wheat varieties ultimately leading to enhanced system productivity, profitability, and sustainability. However, to achieve accelerated and wider scale adoption, concerted efforts are required to create awareness, improve the skills of farmers, and create strong policy support.

\section{Water-Saving Technologies}

Real water saving is referred to as the minimization of the water losses and applying water which is just necessary for plant growth. The amount of water saved can vary, based on the spatial and temporal scales of interest. The water-saving in the RWCS refers to an increase in productivity using less water than is presently being used. The saving of water has additional benefits also in terms of reducing the cost of cultivation (pumping and water charges) and increasing water productivity. The major drawback with puddled transplanted rice is the consumption of excess water, leading to low water productivity. Therefore, different water-saving technologies can be useful in enhancing water use efficiency. These technologies include the cultivation of short-duration crop varieties and transplanting them at the optimum time (Sharma et al., 2020; Singh et al., 2020).

TABLE 1 | Variable cost of cultivation and labor use in rice under dry directseeded rice-zero-till wheat (DDSR-ZTW) in comparison with puddled transplant rice-conventional till wheat (PTR-CTW) in the rice-wheat cropping system in Haryana India (average of 2010-2016).

\begin{tabular}{lcc}
\hline \multirow{2}{*}{ Component } & \multicolumn{2}{c}{ Cost (USD ha ${ }^{-\mathbf{1}}$ ) } \\
\cline { 2 - 3 } & DDSR-ZTW & PTR-CTW \\
\hline Preparatory tillage & 56 & 81 \\
Seed/Nursery/Establishment & 55 & 113 \\
Irrigation & 96 & 125 \\
Weed management & 53 & 15 \\
Total variable cost of cultivation & 448 & 555 \\
Labor use (No. ha ${ }^{-1}$ ) & 56 & 81 \\
\hline
\end{tabular}

Source: Yadav et al. (2021).
The tensiometer-based irrigation scheduling, laser land leveling, direct seeding of rice, bed planting, subsurface drip irrigation system, furrow irrigation, and alternate wetting and drying for rice or applying irrigation at hairline cracking are some of the major technologies for efficient water use in the RWCS. The micro-irrigation system aims to reduce water usage by avoiding surface runoffs and thus improving efficiency of irrigation by $50 \%$ in the RWCS as compared to flood irrigation (Sidhu et al., 2019). It also provides opportunity for provision of nutrients via fertigation. Coupled with automatic irrigation practices, it considerably reduces the number of days of labor requirement and hence lower the production cost. The shift from the puddled transplanting to DDSR saves a large amount of water (20-30\%) and eliminates the need for irrigation for puddling and transplanting. Similarly, the alternate wetting and drying system of irrigation largely reduces the irrigation requirement (30-40\%) after crop establishment both in puddled transplanting as well as direct seeding in rice. The inclusion of short-duration rice cultivars, instead of long ones, increases the water use efficiency by reducing the evapotranspiration losses (Singh et al., 2020). Sprinkler and drip irrigation in DDSR are also potential and emerging opportunities to save irrigation water (Chauhan and Abugho, 2013; Sharda et al., 2017).

Drip irrigation (surface and subsurface) systems provide water and nutrients to the crop root zone, where it can be utilized most effectively. Automation of irrigation in general and drip irrigation in particular with use of sensor network and communication technologies can help in addressing the emerging challenges of inefficiency of water use in the agriculture (Sidhu et al., 2021). Multiple cropping system of summer mung bean-maize-wheat as alternative to the rice-wheat system, enabled by subsurface drip irrigation and fertigation techniques could lead to $30 \%$ savings in irrigation water (Brar et al., 2021). Also, optimizing irrigation may help to reduce methane emissions and net global warming potential in the rice-wheat cropping system (Sapkota et al., 2020).

Furrow irrigation in raised bed could also be an alternative to flood irrigation in the field crops to increase water productivity, particularly in the upland crops. Kumar et al. (2010) reported that by following furrow irrigated bed planting systems in wheat, on an average $40 \%$ water was saved as compared to flat planting with significant increase in water productivity. Kumar et al. (2013a) reported that furrow irrigated raised bed in the rice-wheat system increased wheat yield and yield attributing characters, but rice crop yield and yield attributes did not differ significantly in raised bed and conventional establishment method; however, root growth of rice was more in bed transplanting. There is a scope for raising rice also on raised beds; however, reports of saving water in rice are lacking. However, furrow irrigated raised beds do not always save irrigation water or increase water productivity in comparison with conventionally tilled flat fields, for both rice and wheat (Kukal et al., 2010), and seems to have limited potential under the prevailing soil and climatic conditions of Punjab, India (Singh et al., 2009). There is a scope of its refinement for better outcomes and that warrants for continued research across landscapes. 


\section{Soil Health Improvement}

The fields which witness loss of soil organic matter due to puddling can be fortified with the use of farmyard manure for which the raw materials readily available. In situ crop residue management for rice stubble with above-mentioned machines as well as with microbial decomposers can also help to improve soil organic matter content. Use of bio-fertilizers also presents a unique opportunity to reduce the dependence on fertilizers in the RWCS (Khan, 2018).

Site-specific nutrient management (SSNM) with use of Nutrient Expert $^{\circledR}(\mathrm{NE})$ can be employed for improved productivity and nutrient use efficiency in the RWCS. No-tillage system along with SSNM can increase yield, nutrient use efficiency, and profitability while decreasing greenhouse gases from wheat production in the NW India (Sapkota et al., 2014). The adoption of SSNM significantly increased the net returns by 34 to 43 USD ha ${ }^{-1}$ over farmers' practice of fertilizer application by saving fertilizer input cost (Parihar et al., 2020). Optical sensorbased SSNM saved $20-30 \mathrm{~kg} \mathrm{Nha}^{-1}$ with similar yield under conservation agriculture-based cereal systems compared to recommended dose of fertilizers. Efficient management of $\mathrm{N}$ fertilizers also reduced nitrous oxide emissions by avoiding $\mathrm{N}$ losses via volatilization, leaching, and denitrification. SSNM provides opportunities for enhancing crop productivity, profitability, and nutrient use efficiencies across the different ecologies. Drip irrigation system (subsurface drip irrigation) also helps in improving the N-use efficiency by $20 \%$ over flood irrigation in the rice/maize-based systems (Jat et al., 2019c).

Integrated nutrient management (INM) could help in maintaining soil health and nutrient balances in the RWCS. Data from long-term rice-wheat cropping sequence (30th cycle) indicated that highest rice and wheat grain yields were obtained when $50 \% \mathrm{~N}$ supplied through green manure and farm yard manure, respectively. The soils did not suffer loss of $\mathrm{K}$ and $\mathrm{N}$ where organics replaced 50\% N (Saha et al., 2018). Inclusion of Sesbania green manure in the RWCS may help in sustainable higher productivity with improvement in soil fertility parameters like bulk density, organic carbon, phosphorus, and potassium (Yadav et al., 2010, 2019). Conservation agriculture-based intensification of the RWCS with inclusion of summer mung bean can also improve the soil chemical and biological properties and sustainability of the system (Jat et al., 2016).

\section{Suggested Policy Changes}

A focus on improving data availability for crop succession following in situ residue management can help in promoting

\section{REFERENCES}

Ahmad, I., and Iram, S. (2006). Rice-wheat cropping pattern and resource conservation technologies. Agriculture Overview. Pakistan.com. Available at: http://www.pakissan.com/english/agri.overview/rice.wheat.cropping.pattern. html (Accessed March 21, 2021).

Ambast, S. K., Tyagi, N. K., and Raul, S. K. (2006). Management of declining groundwater in the Trans Indo-Gangetic Plain (India): some options. Agric. Water Manag. 82, 279-296. doi: 10.1016/j.agwat.2005. 06.005 the use of machinery. Furthermore, an emphasis on promoting crop diversification with increasing the Minimum Support Prices for other relevant crops may serve as a positive reminder to the farmers. Subsidy and demonstrations for micro-irrigation equipment can be popularized to promote their usage. The government should also focus on providing infrastructure for ex situ utilization of farm stubble like bio-ethanol plants, biogas plants etc. To monitor soil health, testing campaigns can be organized in the villages to spread awareness about advantages of soil testing.

\section{CONCLUSION}

Northwest India contributes a major portion in the production of rice and wheat and fills the increasing empty stomachs. But with time, the RWCS has faced many sustainability issues, such as depletion of soil fertility, declining ground water table, and environmental degradation. Therefore, there is a need to shift from the conventional RWCS to conservation agriculture and adopt the need-based practices for the sustainable production of crops. More emphasis should be given to developing high-yielding and short-duration rice varieties, which can help in reducing evapotranspiration loss and produce less residue load at harvest. The inclusion of short-duration legumes, like mung bean, can greatly help in increasing the cropping system rice equivalent yield. Less water-demanding crops, such as maize, in place of rice also needs to be explored for sustainable agriculture production. Automation of irrigation methods can help in addressing the emerging challenges of inefficiency of water use in agriculture. Scaling of sustainable intensification technologies (DDSR and zero-till wheat) by strategically leveraging with suitable varieties, creating more awareness on improved management practices by strengthening the existing extension system, and attracting policy support are needed to achieve an enhanced farm income and sustainability in northwest India.

\section{AUTHOR CONTRIBUTIONS}

SD and AY: conceptualization. SD, AY, and DY: writing-original draft. SD, AY, DY, and BC: writing-review and editing. AY, DY, and BC: checked and corrected the final draft. All authors contributed to the article and approved the submitted version. 
Balwinder-Singh, McDonald, A., Kumar, V., Poonia, S. P., Srivastava, A., and Malik, R. K. (2019). Taking the climate risk out of transplanted and direct seeded rice: insights from dynamic simulation in eastern India. Field Crops Res. 239, 92-103. doi: 10.1016/j.fcr.2019.05.014

Banjara, T. R., Bohra, J. S., Kumar, S., Ram, A., and Pal, V. (2021a). Diversification of rice-wheat cropping system improves growth, productivity and energetics of rice in the Indo-Gangetic Plains of India. Agric. Res. 10, 1-10. doi: 10.1007/s40003-020-00533-9

Banjara, T. R., Bohra, J. S., Kumar, S., Singh, T., Shori, A., and Prajapat, K. (2021b). Sustainable alternative crop rotations to the irrigated rice-wheat cropping system of Indo-Gangetic Plains of India. Arch. Agron. Soil Sci. 67, 1-18. doi: 10.1080/03650340.2021.1912324

Bhatt, R., Hossain, A., Busari, M. A., and Meena, R. S. (2020). "Water footprints in rice-based systems of South Asia," in Footprints in Agroecosystem. eds. A. Barnarjee, R. S. Meena and M. K. Jhariya (Singapore: Springer), 272-308.

Bhatt, R., and Kukal, S. S. (2015). Soil physical environment as affected by double zero tillage in rice-wheat cropping system of north-west India. Asian J. Soil Sci. 10, 166-172. doi: 10.15740/HAS/AJSS/10.1/166-172

Bhatt, R., and Kukal, S. S. (2018). Delineation of soil water balance in wheatdry direct seeded rice system under conventional and zero-till conditions in semi-arid. Oryza 55, 574-589. doi: 10.5958/2249-5266.2018.00074.7

Bhatt, R., Kukal, S. S., Arora, S., Busari, M. A., and Yadav, M. (2016). Sustainability issues on rice-wheat cropping system. Int. Soil Water Conserv. Res. 4, 64-74. doi: 10.1016/j.iswcr.2015.12.001

Bhatt, R., Singh, P., Hossain, A., and Timsina, J. (2021). Rice-wheat system in the northwest Indo-Gangetic Plains of South Asia: issues and technological interventions for increasing productivity and sustainability. Paddy Water Environ. 19, 345-365. doi: 10.1007/s10333-021-00846-7

Bhushan, L., Ladha, J. K., Gupta, R. K., Singh, S., Tirol-Padre, A., Saharawat, Y. S., et al. (2007). Saving of water and labor in a rice-wheat system with notillage and direct seeding technologies. Agron. J. 99, 1288-1296. doi: 10.2134/ agronj2006.0227

Bijay-Singh, Sharma, P. K., and Gupta, R. K. (2005). "Impact of rice-wheat cropping system on soil and water quality." in Proceedings of the International Conference on Soil, Water and Environmental Quality, Indian Society of Soil Science. February 1, 2005; New Delhi, India, 216-238.

Bouman, B. (2009). How much water does rice use? Rice Today. 69, 115-133.

Brar, A. S., Kaur, K., Sindhu, V. K., Tsolakis, N., and Srai, J. S. (2021). Sustainable water use through multiple cropping systems and precision irrigation. J. Clean. Prod. 333:130117. doi: 10.1016/j.jclepro.2021.130117

Central Pollution Control Board of India (2017). Continuous Ambient Air Quality Dataset. New Delhi: Ministry of Environment, Forests, and Climate Change.

CGWB (2019). Ground Water Year Book Punjab and Chandigarh (UT) 2018-19 Department of Water Resources, River Development and Ganga Rejuvenation, New Delhi: Ministry of Jal Shakti, Government of India.

Chaudhary, A., Chhokar, R. S., Dhanda, S., Kaushik, P., Kaur, S., Poonia, T. M., et al. (2021). Herbicide resistance to Metsulfuron-Methyl in Rumex dentatus L. in north-west India and its management perspectives for sustainable wheat production. Sustainability 13:6947. doi: 10.3390/su13126947

Chauhan, B. S. (2012). Weed ecology and weed management strategies for dry seeded rice in Asia. Weed Technol. 26, 1-13. doi: 10.1614/WT-D-11-00105.1

Chauhan, B. S., and Abugho, S. B. (2013). Effect of crop residue on seedling emergence and growth of selected weed species in a sprinkler-irrigated zero-till dry-seeded rice system. Weed Sci. 61, 403-409. doi: 10.1614/WSD-12-00147.1

Chauhan, B. S., and Johnson, D. E. (2011). Growth response of direct seeded rice to oxadiazon and bispyribac-sodium in aerobic and saturated soils. Weed Sci. 59, 119-122. doi: 10.1614/WS-D-10-00075.1

Chauhan, B. S., Mahajan, G., Sardana, V., Timsina, J., and Jat, M. L. (2012). Productivity and sustainability of the rice-wheat cropping system in the Indo-Gangetic Plains of the Indian subcontinent: problems, opportunities, and strategies. Adv. Agron. 117, 315-369. doi: 10.1016/B978-0-12-3942784.00006-4

Chauhan, B. S., and Opena, J. (2012). Effect of tillage systems and herbicides on weed emergence, weed growth, and grain yield in dry-seeded rice systems. Field Crops Res. 137, 56-69. doi: 10.1016/j.fcr.2012.08.016

Chhokar, R. S., and Sharma, R. K. (2008). Multiple herbicide resistance in littleseed canarygrass (Phalaris minor): a threat to wheat production in India. Weed Biol. Manage. 8, 112-123. doi: 10.1111/j.1445-6664.2008.00283.x
Chhokar, R. S., Sharma, R. K., Gill, S. C., Singh, R., and Singh, G. P. (2017). "Management of herbicide resistant weeds for sustainable wheat production." in Proceedings of the Biennial Conference on "Doubling Farmers' Income by 2022: The Role of Weed Science”, MPUA\&T, Udaipur, India, 32.

Chhokar, R. S., Sharma, R. K., Jat, G. R., Pundir, A. K., and Gathala, M. K. (2007). Effect of tillage and herbicides on weeds and productivity of wheat under rice-wheat growing system. Crop Prot. 26, 1689-1696. doi: 10.1016/j. cropro.2007.01.010

Chhokar, R. S., Sharma, R. K., and Sharma, I. (2012). Weed management strategies in wheat-A review. J. Wheat Res. 4, 1-21.

Choudhary, M., Jat, H. S., Datta, A., Yadav, A. K., Sapkota, T. B., Mondal, S., et al. (2018b). Sustainable intensification influences soil quality, biota, and productivity in cereal-based agroecosystems. Appl. Soil Ecol. 126, 189-198. doi: 10.1016/j.apsoil.2018.02.027

Choudhary, K. M., Jat, H. S., Nandal, D. P., Bishnoi, D. K., Sutaliya, J. M., Choudhary, M., et al. (2018a). Evaluating alternatives to rice-wheat system in western Indo-Gangetic Plains: crop yields, water productivity and economic profitability. Field Crops Res. 218, 1-10. doi: 10.1016/j.fcr. 2017.12.023

DACFW (2019). Report of the Committee: Review of the Scheme Promotion of Agricultural Mechanisation for in-situ Management of Crop Residue in States of Punjab, Haryana, Uttar Pradesh and NCT of Delhi. Department of Agriculture, Cooperation \& Farmers Welfare, Krishi Bhawan, New Delhi.

Dhanda, S., Chaudhary, A., Kaur, S., and Bhullar, M. S. (2020). Herbicide resistance in Rumex dentatus against metsulfuron herbicide in Punjab and Haryana, India. Indian J. Weed Sci. 52, 259-264.

Dhillon, B. S., Kataria, P., and Dhillon, P. K. (2010). National food security vis-à-vis sustainability of agriculture in high crop productivity regions. Curr. Sci. 98, 33-36.

Dhillon, B. S., Kumar, V., Sagwal, P., Kaur, N., Mangat, G. S., and Singh, S. (2021). Seed priming with potassium nitrate and gibberellic acid enhances the performance of dry direct seeded rice (Oryza sativa L.) in north-western India. Agronomy 11. doi: 10.3390/agronomy11050849

Dhillon, B. S., and Mangat, G. S. (2018). "Direct seeded rice in Punjab: opportunities and challenges." in Technology for Rice Production, Proceedings of National Seminar on Sustainable Rice Production Technology for Increasing the Farmers' Income, Indra Gandhi Krishi Vishav vidyalaya, Raipur, Chhatisgarh, India, 20-21 January 2018, 535-538.

FAOSTAT (2021) Food and Agriculture Data. Food and Agriculture Organization of the United Nations, Rome.

Farmaha, F. S., Singh, P., and Singh, B. (2021). Spatial and temporal assessment of nitrate- $\mathrm{N}$ under rice-wheat system in riparian wetlands of Punjab, northwestern India. Agronomy. 11:1284. doi: 10.3390/agronomy11071284

Farooq, M, and Siddique, KH. (2014). Conservation Agriculture. Springer, Berlin, 665.

Franke, A. C., Mcroberts, N., Marshall, G., Malik, R. K., Singh, S., and Nehra, A. S. (2003). Survey of Phalaris minor in the Indian rice-wheat system. Exp. Agric. 39, 253-265. doi: 10.1017/S0014479703001303

Gartaula, H., Sapkota, T. B., Khatri-Chhetri, A., Prasad, G., and Badstue, L. (2020). Gendered impacts of greenhouse gas mitigation options for rice cultivation in India. Clim. Chang. 163, 1045-1063. doi: 10.1007/s10584020-02941-w

Gathala, M. K., Kumar, V., Sharma, P. C., Saharawat, Y. S., Jat, H. S., Singh, M., et al. (2013). Optimizing intensive cereal-based cropping systems addressing current and future drivers of agricultural change in the northwestern IndoGangetic Plains of India. Agric. Ecosyst. Environ. 177, 85-97. doi: 10.1016/j. agee.2013.06.002

Gill, JS. (1992). Land Use, Conservation, Management and Development of Land Resources of Punjab. Report of Department of Soil Conservation and Engineering, Chandigarh, Punjab.

Godfray, H. C. J., and Garnett, T. (2014). Food security and sustainable intensification. Phil. Trans. R. Soc. B 369:20120273. doi: 10.1098/rstb 2012.0273

GoI (2017). Report of 5th Census of Minor Irrigation Schemes. Government of India, Ministry of Water Resources, River Development and Ganga Rejuvenation, Minor Irrigation (Statistics) Wing, November 2017.

Gupta, D. K., Bhatia, A., Kumar, A., Das, T. K., Jain, N., Malyan, T. R., et al. (2016). Mitigation of greenhouse gas emission from rice-wheat system of 
the Indo-Gangetic Plains. Through tillage, irrigation and fertilizer management. Agric. Ecosyst. 230, 1-9. doi: 10.1016/j.agee.2016.05.023

Gupta, P., Sahai, S., Singh, N., Dixit, C., Singh, D., Sharma, C., et al. (2004). Residue burning in rice-wheat cropping system: causes and implications. Curr. Sci. 87, 1713-1717.

Gupta, R. K., and Sayre, K. (2007). Conservation agriculture in South Asia. J. Agric. Sci. 145, 207-214. doi: 10.1017/S0021859607006910

Haryana Economic Survey (2019-20). Department of Economic and Statistical Analysis. Chandigarh: Government of Haryana.

Hira, G. S. (2009). Water management in northern states and the food security of India. J. Crop Improv. 23, 136-157. doi: 10.1080/1542752080 2645432

Hira, G. S., Jalota, S. K., and Arora, V. K. (2004). Efficient Management of Water Resources for Sustainable Cropping in Punjab. Research Bulletin, Department of Soils, Punjab Agricultural University, Ludhiana, 20.

Hobbs, P. R., Sayre, K., and Gupta, R. (2008). The role of conservation agriculture in sustainable agriculture. Phil. Trans. R. Soc. B 363, 543-555. doi: 10.1098/ rstb.2007.2169

Hossain, A., Sarkar, S., Barman, M., Garai, S., Bhatt, R., Islam, M. T., et al. (2021). "Natural resources intensification and footprints management for sustainable food system," in Agroecological Footprints Management for Sustainable Food System eds. A. Banerjee, R. S. Meena, M. K. Jhariya and D. K. Yadav (Singapore: Springer), 25-68.

Humphreys, E., and Christen, E. W. (2020). "The realities of water 'saving' in rice-wheat systems in north-west India." in Success Stories in Agricultural Water Management Research for Development. ed. E. W. Christen (Australian Centre for International Agricultural Research), 42-57.

Humphreys, E., and Gaydon, D. S. (2015). Options for increasing the productivity of the rice-wheat system of north-west India while reducing groundwater depletion. Part 2. Is conservation agriculture the answer? Field Crops Res. 173, 81-94. doi: 10.1016/j.fcr.2014.11.019

Humphreys, E., Kukal, S. S., Christen, E. W., Hira, G. S., and Sharma, R. K. (2010). Halting the groundwater decline in north-west India-which crop technologies will be winners? Adv. Agron. 109, 155-217. doi: 10.1016/ B978-0-12-385040-9.00005-0

Jat, M. L., Dagar, J. C., Sapkota, T. B., Govaerts, B., Ridaura, S. L., Saharawat, Y. S., et al. (2016). Climate change and agriculture: adaptation strategies and mitigation opportunities for food security in South Asia and Latin America. Adv. Agron. 137, 127-235. doi: 10.1016/bs.agron.2015.12.005

Jat, M. L., Chakarborty, D., Ladha, J. K., Rana, D. S., Gathala, M. K., McDonald, A., et al. (2020). Conservation agriculture for sustainable intensification in South Asia. Nat. Sustain. 3, 336-343. doi: 10.1038/s41893-020-0500-2

Jat, H. S., Datta, A., Choudhary, M., Sharma, P. C., Yadav, A. K., Choudhary, V., et al. (2019a). Climate smart agriculture practices improve soil organic carbon pools, biological properties and crop productivity in cereal-based systems of north-west India. Catena 181:104059. doi: 10.1016/j. catena.2019.05.005

Jat, M. L., Gathala, M. K., Ladha, J. K., Saharawat, Y. S., Jat, A. S., Kumar, V., et al. (2009). Evaluation of precision land leveling and double zero-till systems in the rice-wheat rotation: water use, productivity, profitability and soil physical properties. Soil Till Res. 105, 112-121. doi: 10.1016/j. still.2009.06.003

Jat, M. L., Jat, H., Agarwal, T., Bijarniya, D., Kakraliya, S. K., Choudhary, K. M., et al. (2020). A Compendium of Key Climate Smart Agriculture Practices in Intensive Cereal Based Systems of South Asia. International Maize and Wheat Improvement Center (CIMMYT), New Delhi, India, 42.

Jat, N. K., Kumar, A., Meena, S. R., Rana, D. S., Meena, B. P., and Rana, K. S. (2012). Influence of integrated nutrient management on the productivity, quality and soil health of maize (Zea mays)-wheat (Triticum aestivum) cropping system. Indian J. Agron. 57, 327-332.

Jat, H. S., Kumar, P., Sutaliya, J. M., Kumar, S., Choudhary, M., Singh, Y., et al. (2019b). Conservation agriculture based sustainable intensification of basmati rice-wheat system in north-west India. Arch. Agron. Soil Sci. 65, 1370-1386. doi: 10.1080/03650340.2019.1566708

Jat, H. S., Sharma, P. C., Datta, A., Choudhary, M., Kakraliya, S. K., Sidhu, H. S., et al. (2019c). Re-designing irrigated intensive cereal systems through bundling precision agronomic innovations for transitioning towards agricultural sustainability in north-west India. Sci. Rep. 9, 1-14. doi: 10.1038/s41598019-54086-1
Kang, B. S., Singh, K., Singh, D., Garg, B. R., Lal, R., and Velayutham, M. (2009). Viable alternatives to the rice-wheat cropping system in Punjab. J. Crop Improv. 23, 300-318. doi: 10.1080/15427520902809912

Kaur, T., Bhullar, M. S., and Kaur, S. (2019). Control of herbicide resistant Phalaris minor by pyroxasulfone in wheat. Indian J. Weed Sci. 51, 123-128. doi: 10.5958/0974-8164.2019.00028.5

Kaur, N., and Kaur, A. (2021). Capitalist agriculture, COVID-19 and agrarian labour relations in Punjab, India. J. Agrar Change 21, 638-650. doi: 10.1111/ joac. 12428

Kaushal, R. (2021). Direct seeding of rice to be done in 8 lac hectare this year in the state. Dainik Bhaskar Ludhiana, May 13.

Khan, H. I. (2018). Appraisal of bio-fertilizers in rice: to supplement inorganic chemical fertilizer. Rice Sci. 25, 357-362. doi: 10.1016/j.rsci.2018.10.006

Kukal, S. S., Jat, M. L., and Sidhu, H. S. (2014). Improving water productivity of wheat-based cropping systems in South Asia for sustained productivity. Adv. Agron. 127, 157-258. doi: 10.1016/B978-0-12-800131-8.00004-2

Kukal, S. S., Sudhir-Yadav, Humphreys, E., Amanpreet-Kaur, Yadvinder-Singh, Thaman, S., et al. (2010). Factors affecting irrigation water savings in raised beds in rice and wheat. Field Crops Res. 118, 43-50. doi: 10.1016/j.fcr.2010.04.003

Kumar, V., Bellinder, R. R., Gupta, R. K., Malik, R. K., and Brainard, D. C. (2008). Role of herbicide-resistant rice in promoting resource conservation technologies in rice-wheat cropping systems of India: a review. Crop Prot. 27, 290-301. doi: 10.1016/j.cropro.2007.05.016

Kumar, V., Jat, H. S., Sharma, P. C., Gathala, M. K., Malik, R. K., Kamboj, B. R., et al. (2018). Can productivity and profitability be enhanced in intensively managed cereal systems while reducing the environmental footprint of production? Assessing sustainable intensification options in the breadbasket of India. Agric. Ecosyst. Environ. 252, 132-147. doi: 10.1016/j.agee.2017.10.006

Kumar, V., Kumar, P., and Singh, R. (2013a). Growth and yield of rice-wheat cropping sequence in raised bed planting system. Indian J. Agric. Res. 47, $157-162$.

Kumar, V., and Ladha, J. K. (2011). Direct seeding of rice: recent developments and future research needs. Adv. Agron. 111, 297-313. doi: 10.1016/ B978-0-12-387689-8.00001-1

Kumar, V., Ladha, J. K., and Gathala, M. K. (2009). "Direct drill-seeded rice: a need of the day." in Annual Meeting of Agronomy Society of America November 1-5, 2009, Pittsburgh.

Kumar, V., Saharawat, Y. S., Gathala, M. K., Jat, A. S., Singh, S. K., Chaudhary, N., et al. (2013b). Effect of different tillage and seeding methods on energy use efficiency and productivity of wheat in the Indo-Gangetic Plains. Field Crops Res. 142, 1-8. doi: 10.1016/j.fcr.2012.11.013

Kumar, S., Sharma, D. K., Singh, D. R., Biswas, H., Praveen, K. V., and Sharma, V. (2019). Estimating loss of ecosystem services due to paddy straw burning in north-west India. Int. J. Agric. Sust. 17, 146-157. doi: 10.1080/14735903. 2019.1581474

Kumar, A., Sharma, K. D., and Yadav, A. (2010). Enhancing yield and water productivity of wheat (Triticum aestivum) through furrow irrigated raised bed system in the Indo-Gangetic Plains of India. Indian J. Agric. Sci. 80, 198-202.

Ladha, J. K., Kumar, V., Alam, M. M., Sharma, S., Gathala, M. K., Chandna, P., et al. (2009). "Integrating crop and resource management technologies for enhanced productivity, profitability and sustainability of the rice-wheat system in South Asia," in Integrated Crop and Resource Management in the RiceWheat System of South Asia. eds. J. K. Ladha, Y. Singh, O. Erenstein and B. Hardy (Los Banos, Philippines: International Rice Research Institute), 69-108.

Lal, R. (2004). Soil carbon sequestration impacts on global climate change and food security. Science 304, 1623-1627. doi: 10.1126/science.1097396

Lalik, R., Sharma, S., Idris, M., Singh, A. K., Singh, S. S., Bhatt, B. P., et al. (2014). Integration of conservation agriculture with best management practices for improving system performance of the rice-wheat rotation in the eastern Indo-Gangetic Plains of India. Agric. Ecosyst. Environ. 195, 68-82. doi: 10.1016/j.agee.2014.06.001

Lohan, S. K., Jat, H. S., Yadav, A. K., Sidhu, H. S., Jat, M. L., Choudhary, M., et al. (2018). Burning issues of paddy residue management in north-west states of India. Renew. Sust. Energ. Rev. 81, 693-706. doi: 10.1016/j. rser.2017.08.057

Mahajan, G., Singh, S., and Chauhan, B. S. (2012). Impact of climate change on weeds in the rice-wheat cropping system. Curr. Sci. 102, 1254-1255. 
Mahajan, G., Timsina, J., and Singh, K. (2011). Performance and water use efficiency of rice relative to establishment methods in northwestern IndoGangetic Plains. J. Crop Improv. 25, 597-617. doi: 10.1080/15427528.2011.599480

NAAS (2017). Innovative Viable Solution to Rice Residue Burning in Rice-Wheat Cropping System Through Concurrent Use of Super Straw Management SystemFitted Combines and Turbo Happy Seeder. Policy Brief No. 2, National Academy of Agricultural Sciences, New Delhi.

Nandan, R., Poonia, S. P., Singh, S. S., Nath, C. P., Kumar, V., Malik, R. K., et al. (2021). Potential of conservation agriculture modules for energy conservation and sustainability of rice-based production systems of IndoGangetic Plain region. Environ. Sci. Pollut. Res. 28, 246-261. doi: 10.1007/ s11356-020-10395-x

Panneerselvam, P., Kumar, V., Banik, N. C., Kumar, V., Parida, N., Wasim, I., et al. (2020). Transforming labor requirement, crop yield, and profitability with precision dry-direct seeding of rice and integrated weed management in eastern India. Field Crop Res. 259:107961. doi: 10.1016/j.fcr.2020.107961

Parihar, C. M., Jat, H. S., Yadvinder-Singh, J. S. L., Kakraliya, S. K., and Nayak, H. S. (2020). Precision nutrient management for higher nutrient use efficiency and farm profitability in irrigated cereal-based cropping systems. Indian J. Fert. 16, 1000-1014.

Pathak, H., Ladha, J. K., Aggarwal, P. K., Peng, S., Das, S., Singh, Y., et al. (2003). Trends of climatic potential and on-farm yields of rice and wheat in the Indo-Gangetic Plains. Field Crops Res. 80, 223-234. doi: 10.1016/ S0378-4290(02)00194-6

Pathak, H., Saharawat, Y. S., Gathala, M. K., Mohanty, S., and Ladha, J. K. (2009). "Simulating environmental impact of resource-conserving technologies in the rice-wheat system of the Indo-Gangetic Plains," in Integrated Crop and Resource Management in the Rice-Wheat System of South Asia. eds. J. K. Ladha, Y. Singh, O. Erenstein and B. Hardy (Los Banos, Philippines: International Rice Research Institute), 321-333.

Pathak, H., Tewar, A. N., Sankhyan, S., Dubey, D. S., Mina, U., Singh, V. K., et al. (2011). Direct-seeded rice: potential, performance and problems - a review. Curr. Adv. Agric. Sci. 3, 77-88.

Pradhan, P., Verma, A., Pandey, M., and Lal, K. (2018). A review on Biasi cultivation in Chhattisgarh. Acta Sci. Agric. 2, 126-130.

Punjab Economic Survey (2019-20). Economic and Statistical Planning, Department of Planning, Government of Punjab, Chandigarh.

Ram, H., Singh, Y., Saini, K. S., Kler, D. S., and Timsina, J. (2013). Tillage and planting methods effects on yield, water use efficiency and profitability of soybean-wheat system on a loamy sand soil. Exp. Agric. 49, 524-542. doi: $10.1017 /$ S0014479713000264

Rao, A. N., Johnson, D. E., Sivaprasad, B., Ladha, J. K., and Mortimer, A. M. (2007). Weed management in direct-seeded rice. Adv. Agron. 93, 153-255. doi: 10.1016/S0065-2113(06)93004-1

Rashid, M. H., Alam, M. M., Khan, M. A. H., and Ladha, J. K. (2009). Productivity and resource use of direct (drum)-seeded and transplanted rice in puddled soils in rice-rice and rice-wheat ecosystem. Field Crops Res. 113, 274-281. doi: 10.1016/j.fcr.2009.06.004

Sah, G., Shah, S. C., Sah, S. K., Thapa, R. B., McDonald, A., Sidhu, H. S., et al. (2014). Effects of tillage and crop establishment methods, crop residues, and nitrogen levels on soil properties and crop yields under rice-wheat system in the terai region of Nepal. Glob. J. Biol. Agric. Health Sci. 3, 139-147.

Saha, S., Saha, B., Ray, M., Mukhopadhyay, S. K., and Halder, P. (2018). Integrated nutrient management (INM) on yield trends and sustainability, nutrient balance and soil fertility in a long-term (30 years) rice-wheat system in the Indo-Gangetic Plains of India. J. Plant Nutri. 41, 2365-2375. doi: 10.1080/01904167.2018.1510509

Saharawat, Y. S., Singh, B., Malik, R. K., Ladha, J. K., Gathala, M., Jat, M. L., et al. (2010). Evaluation of alternative tillage and crop establishment methods in a rice-wheat rotation in North Western IGP. Field Crops Res. 116, 260-267. doi: $10.1016 /$ j.fcr.2010.01.003

Sapkota, A., Haghverdi, A., Avila, C. C. E., and Ying, S. C. (2020). Irrigation and greenhouse gas emissions: a review of field-based studies. Soil Syst. 4:20. doi: $10.3390 /$ soilsystems 4020020

Sapkota, T. B., Jat, R. K., Singh, R. G., Jat, M. L., Stirling, C. M., Jat, M. K., et al. (2017). Soil organic carbon changes after seven years of conservation agriculture in a rice-wheat system of the eastern Indo-Gangetic Plains. Soil Use Manag. 33, 81-89. doi: 10.1111/sum.12331
Sapkota, T. B., Majumdar, K., Jat, M. L., Kumar, A., Bishnoi, D. K., McDonald, A. J., et al. (2014). Precision nutrient management in conservation agriculture based wheat production of Northwest India: Profitability, nutrient use efficiency and environmental footprint. Field Crops Res. 155, 233-244. doi: 10.1016/j. fcr.2013.09.001

Saurabh, K., Rao, K. K., Mishra, J. S., Kumar, R., Poonia, S. P., Samal, S. K., et al. (2021). Influence of tillage based crop establishment and residue management practices on soil quality indices and yield sustainability in rice-wheat cropping system of eastern Indo-Gangetic Plains. Soil Till Res. 206:104841. doi: 10.1016/j.still.2020.104841

Sharda, R., Mahajan, G., Siag, M., Singh, A., and Chauhan, B. S. (2017). Performance of drip-irrigated dry-seeded rice (Oryza sativa L.) in South Asia. Paddy Water Environ. 15, 93-100. doi: 10.1007/s10333-016-0531-5

Sharma, M., and Dikshit, O. (2016). Comprehensive study on air pollution and green house gases (GHGs) in Delhi. Available at: http://delhi.gov.in/ DoIT/Environment/PDFs/Final_Report (Accessed November 16, 2021).

Sharma, S., Singh, P., and Kumar, S. (2020). Responses of soil carbon pools, enzymatic activity, and crop yields to nitrogen and straw incorporation in a rice-wheat cropping system in north-western India. Front. Sustain. Food Syst. 4:532704. doi: 10.3389/fsufs.2020.532704

Shekhawat, K., Rathore, S. S., and Chauhan, B. S. (2020). Weed management in dry-direct seeded rice: a review on challenges and opportunities for sustainable rice production. Agronomy. 10:1264. doi: 10.3390/ agronomy10091264

Sidhu, H. S., Jat, M. L., Singh, Y., Sidhu, R. K., Gupta, N., Singh, P., et al. (2019). Sub-surface drip fertigation with conservation agriculture in a ricewheat system: a breakthrough for addressing water and nitrogen use efficiency. Agric. Water Manag. 216, 273-283. doi: 10.1016/j.agwat.2019.02.019

Sidhu, R. K., Kumar, R., Rana, P. S., and Jat, M. L. (2021). Chapter five automation in drip irrigation for enhancing water use efficiency in cereal systems of South Asia: status and prospects. Adv. Agron. 167, 247-300. doi: 10.1016/bs.agron.2021.01.002

Sidhu, H. S., Manpreet, S., Humphreys, E., Yadvinder-Singh, Balwinder-Singh, Dhillon, S. S., et al. (2007). The happy seeder enables direct drilling of wheat into rice stubble. Aust. J. Exp. Agric. 47, 844-854. doi: 10.1071/ EA06225

Sidhu, B. S., Sharda, R., and Singh, S. (2021). Spatio-temporal assessment of groundwater depletion in Punjab. India. Groundw. Sustain. Dev. 12:100498. doi: 10.1016/j.gsd.2020.100498

Sidhu, H. S., Singh, M., Singh, Y., Blackwell, J., Lohan, S. K., Humphreys, E., et al. (2015). Development and evaluation of the turbo happy seeder for sowing wheat into heavy rice residues in NW India. Field Crops Res. 184, 201-212. doi: 10.1016/j.fcr.2015.07.025

Singh, G. (2018). Role of Different Business Models in Scaling and Adoption of Happy Seeder Technology in Haryana and Punjab. Indian institute of management - Ahmedabad Vastrapur, Ahmedabad, Gujarat.

Singh, A. K., Alagusundaram, K., Kumar, A., Singh, R., Sehgal, V. K., Chahal, V. P., et al. (2019). In-Situ Crop Residue Management: Key Outcome and Learning. Division of Agricultural Extension, ICAR, New Delhi, 30.

Singh, S., Bhushan, L., Ladha, J. K., Gupta, R. K., Rao, A. N., and Sivaprasad, B. (2006). Weed management in dry-seeded rice (Oryza sativa L.) cultivated on furrow irrigated raised bed planting system. Crop Prot. 25, 487-495. doi: 10.1016/j.cropro.2005.08.004

Singh, Y., Humphreys, E., Kukal, S. S., Singh, B., Amanpreet-Kaur, Thaman, S., et al. (2009). Crop performance in permanent raised bed rice-wheat cropping system in Punjab. India. Field Crops Res. 110, 1-20. doi: 10.1016/j.fcr.2008.06.009

Singh, S., Ladha, J. K., Gupta, R. K., Bhushan, L., Rao, A. N., Sivaprasad, B., et al. (2007). Evaluation of mulching, intercropping with Sesbania and herbicide use for weed management in dry-seeded rice (Oryza sativa L.). Crop Prot. 26, 518-524. doi: 10.1016/j.cropro.2006.04.024

Singh, B., Shan, Y. H., Johnson-Beebout, S. E., Yadvinder-Singh, and Buresh, R. J. (2008). Crop residue management far lowland rice-based cropping systems in Asia. Adv. Agron. 98, 117-199. doi: 10.1016/S0065-2113(08)00203-4

Singh, Y., and Sidhu, H. S. (2014). Management of cereal crop residues for sustainable rice-wheat production system in the Indo-Gangetic Plains of India. Proc. Indian Nat. Sci. Acad. 80, 95-114. doi: 10.16943/ptinsa/2014/v80i1/55089

Singh, P., Singh, G., and Sodhi, G. S. (2020). On-farm participatory assessment of short and medium duration rice genotypes in South-Western Punjab. Indian J. Ext. Educ. 56, 88-94. 
Singh, R., Yadav, D. B., Ravisankar, N., Yadav, A., and Singh, H. (2019). Crop residue management in rice-wheat cropping system for resource conservation and environmental protection in north-western India. Environ. Dev. Sustain. 22, 3871-3896. doi: 10.1007/s10668-019-00370-z

Singh, R., Yadav, D. B., Yadav, A., and Punia, S. S. (2021). Characterization of herbicide use and factors responsible for herbicide resistance in Phalaris minor in wheat in Haryana. India. Crop Prot. 144:105581. doi: 10.1016/j. cropro.2021.105581

Statistical Abstract of Haryana (2018-19). Publication No. 1227. Issued by Department of Economic and Statistical Analysis, Haryana, Government of Haryana 2020.

Statistical Abstract of Punjab (2019). Economic and Statistical Organization, Publication No. 960 Government of Punjab. Available at: www.esopb.gov.in (Accessed November 16, 2021).

Sudhir-Yadav, Kumar, V, Singh, S, Kumar, RM, Sharma, S, Tripathi, R, et al. (2017). Growing rice in eastern India: new paradigms of risk reduction and improving productivity. In: S Mohanty and PG Chengappa, Mruthyunjaya, and Ladha, JK, S Baruah, E Kannan and AV Manjunatha, The Future Rice Strategy for India. Amsterdam: Academic Press, Elsevier, 221-258.

Tilman, D., Balzer, C., Hill, J., and Befort, B. L. (2011). Global food demand and the sustainable intensification of agriculture. Proc. Natl. Acad. Sci. 108, 20260-20264. doi: 10.1073/pnas.1116437108

Tripathi, S. C., Mongia, A. D., Sharma, R. K., Kharub, A. S., and Chhokar, R. S. (2005). Wheat productivity at different sowing time in various agro-climatic zones of India. SAARC J. Agric. 3, 191-201.

USDA (2019). India: Grain and Feed Annual 2019: Grain Report Number: IN 9025. USDA Foreign Agricultural Service, Global Agricultural Information Network, Washington, DC.

Venkatesh, M. S., Hazra, K. K., Ghosh, P. K., Khuswah, B. L., Ganeshamurthy, A. N., Ali, M., et al. (2017). Long-term effect of crop rotation and nutrient management on soil-plant nutrient cycling and nutrient budgeting in IndoGangetic Plains of India. Arch. Agron. Soil Sci. 63, 2007-2022. doi: 10.1080/ 03650340.2017 .1320392

Vetter, S. H., Sapkota, T. B., Hillier, J., Stirling, C. M., Macdiarmid, J. I., Aleksandrowicz, L., et al. (2017). Greenhouse gas emissions from agricultural food production to supply Indian diets: implications for climate change mitigation. Agric. Ecosyst. Environ. 237, 234-241. doi: 10.1016/j.agee.2016.12.024

Walia, S. S., Gill, M. S., Bhushan, B., Phutela, R. P., and Aulakh, C. S. (2011). Alternate cropping systems to rice (Oryza sativa)-wheat (Triticum aestivum) for Punjab. Indian J, Agron. 56, 20-27.

Wei, T., Zhang, P., Wang, K., Ding, R., Yang, B., Nie, J., et al. (2015). Effects of wheat straw incorporation on the availability of soil nutrients and enzyme activities in semiarid areas. PLoS One 10:e0120994. doi: 10.1371/journal. pone.0120994
Workie, E., Mackolil, J., Nyikal, J., and Ramadas, S. (2020). Deciphering the impact of COVID-19 pandemic on food security, agriculture, and livelihoods: a review of the evidence from developing countries. Curr. Res. Environ. Sustain. 2:100014. doi: 10.1016/j.crsust.2020.100014

Yadav, R. L., Dwivedi, B. S., Prasad, K., Tomar, O. K., Shurpal, N. J., and Pandey, P. S. (2000). Yield trends, and changes in soil organic-C and available NPK in a long-term rice-wheat system under integrated use of manures and fertilizers. Field Crops Res. 68, 219-246. doi: 10.1016/S03784290(00)00126-X

Yadav, D. B., Suneja, S., Sagwal, O. P., Yadav, A., Punia, S. S., Hasija, R. C., et al. (2010). Long term effect of continuous or rotational use of herbicides and green manuring on weed flora, weed seed bank, soil properties and microbial population in rice-wheat sequence. Environ. Ecol. 28, 439-447.

Yadav, D. B., Yadav, A., and Punia, S. S. (2019). Impact of long-term green manuring and herbicides on weed biomass, crop productivity and profitability in rice (Oryza sativa)-wheat (Triticum aestivum) cropping system in Haryana. Indian J. Agron. 64, 172-179.

Yadav, D. B., Yadav, A., Punia, S. S., and Chauhan, B. S. (2016). Management of herbicide-resistant Phalaris minor in wheat by sequential or tank-mix applications of pre- and post-emergence herbicides in north-western IndoGangetic Plains. Crop Prot. 89, 239-247. doi: 10.1016/j.cropro.2016.07.012

Yadav, D. B., Yadav, A., Vats, A. K., Gill, G., and Malik, R. K. (2021). Direct seeded rice in sequence with zero-tillage wheat in north-western India: addressing system-based sustainability issues. SN Appl. Sci. 3:844. doi: 10.1007/ s42452-021-04827-7

Conflict of Interest: The authors declare that the research was conducted in the absence of any commercial or financial relationships that could be construed as a potential conflict of interest.

Publisher's Note: All claims expressed in this article are solely those of the authors and do not necessarily represent those of their affiliated organizations, or those of the publisher, the editors and the reviewers. Any product that may be evaluated in this article, or claim that may be made by its manufacturer, is not guaranteed or endorsed by the publisher.

Copyright (c) 2022 Dhanda, Yadav, Yadav and Chauhan. This is an open-access article distributed under the terms of the Creative Commons Attribution License (CC BY). The use, distribution or reproduction in other forums is permitted, provided the original author(s) and the copyright owner(s) are credited and that the original publication in this journal is cited, in accordance with accepted academic practice. No use, distribution or reproduction is permitted which does not comply with these terms. 